\title{
EFFECT OF POLYPHENOL OXIDASE (PPO) AND AIR TREATMENTS ON TOTAL PHENOL AND TANNIN CONTENT OF COCOA NIBS ${ }^{1}$
}

\author{
Edy Sousa de BRITO ${ }^{2, *}$, Nelson Horacio Pezoa GARCÍA ${ }^{3}$, Allan César AMÂNCIO ${ }^{3}$
}

\section{SUMMARY}

Cocoa flavour is greatly influenced by polyphenols. These compounds undergo a series of transformations during cocoa processing leading to the characteristic cocoa flavour. The use of exogenous polyphenol oxidase (PPO) proved to be useful to reduce polyphenol content in cocoa nibs. The effect of a PPO associated or not with air over total phenol and tannin content was evaluated. Cocoa nibs were autoclaved and treated with a PPO or water in the absence or presence of an air flow for $0.5,1,2$ and 3 hours. Total phenol content was reduced in PPO or water treatments, but when associated with air there was an increase in phenol content. Tannin content was reduced only by the treatment with water and air.

Keywords: cocoa; processing; PPO; enzyme; air; Theobroma cacao.

\section{RESUMO}

EFEITO DOS TRATAMENTOS COM POLIFENOL OXIDASE (PPO) E AR SOBRE O TEOR DE FENÓIS TOTAIS E TANINOS EM NIBS DE CACAU. O sabor do cacau é fortemente influenciado pelos polifenóis. Esses compostos sofrem uma série de transformações durante o processamento do cacau dando origem ao sabor característico do cacau. O uso de polifenol oxidase (PPO) exógena mostrou ser útil na redução do teor de polifenóis em nibs de cacau. O efeito de uma PPO associada ou não com ar sobre o teor de fenóis totais e taninos foi avaliado. Nibs de cacau foram autoclavados e tratados com PPO ou água na presença ou não de um fluxo de ar por 0,$5 ; 1 ; 2$ e 3 horas. O teor de fenóis totais foi reduzido nos tratamentos com PPO ou água, mas quando associados com ar houve um aumento desses teores. O teor de taninos foi reduzido apenas pelo tratamento com água e ar.

Palavras-chave: cacau; processamento; PPO; enzima; ar; Theobroma cacao.

\section{1 - INTRODUCTION}

During cocoa fermentation the phenolic compounds originally compacted into vacuoles of specific cells diffuse through the cotyledon [7]. The phenols are oxidized and the resulting compounds associate reversibly with proteins by hydrogen bonds or, irreversibly, by condensation with reactive groups of amino acids, peptides, proteins and polysaccharides. These reactions are important to the development of cocoa flavour $[1,8]$. The total phenols in cocoa get reduced during fermentation to $30 \%$ of the initial value and the (-)-epicatechin, principal substrate of cocoa polyphenol oxidase (PPO), is reduced by $90 \%$, with a proportional increase in catechin content $[2,10,15]$. Polyphenol reduction during drying was attributed to enzymatic browning followed by non-enzymatic browning from quinone polymerization. The PPO would not have appropriate conditions to react during fermentation, but during drying with the increase in $\mathrm{pH}$ and high $\mathrm{O}_{2}$ uptake, the conditions will be appropriate to phenolic oxidation [4]. However, the reduction of the phenolic compounds could not be explained only by enzymatic oxidation since, in the fifth day of fermentation, the PPO activity was reduced from 5 to $13 \%$ of the beginning with a complete or strong inactivation $[6,12,14]$. Information about other changes in phenolic content during further cocoa processing is rare [16].

Today there is a great interest in cocoa polyphenols not only because of their contribution to flavour but also for their antioxidant activity and possible beneficial health effects [17]. Total phenol content in cocoa varies from 12 to $18 \%$ of defatted and dry weight. The principal compounds are (+)-catechin, (-)-epicatechin and 60\% of proanthocyanidins, of which half are dimers. Other compounds identified are quercetin, quercetrin and $p$ coumaric, cafeic and clhorogenic acids [10, 13].

The use of enzymes in cocoa nibs was applied with success to reduce polyphenol contents by about $25 \%$ $[3,19]$. These authors reported a greater polyphenol reduction when nibs were autoclaved, which facilitates enzyme penetration into tissues and enzyme action. FERNÁNDEZ BARBERY [3] also demonstrated that astringency and bitterness were reduced by polyphenoloxidase action, which contributed to a better acceptance of the cocoa products. The use of Polyphenol oxidase in cocoa processing was also suggested, since these enzymes were involved in the formation of aldehydes from amino acids [8].

In this work we studied the effect of polyphenol oxidase and air effects on the total phenol and tannin content of cocoa nibs.

\section{2 - MATERIAL AND METHODS}

\section{1 - Processing}

Fermented and dried "Forastero" cocoa beans were supplied by INDECA S.A. (Embú-SP, Brasil). A cut-test

${ }^{1}$ Recebido para publicação em 30/04/01. Aceito para publicação em 23/10/01.

${ }^{2}$ Embrapa Agroindústria Tropical. R. Dra Sara Mesquita, 2270, PICI, Fortaleza-CE, CEP - 60511-110. E-mail: edy@cnpat.embrapa.br

${ }^{3}$ Departamento de Tecnologia de Alimentos, FEA, UNICAMP. Caixa Postal 6121, CEP 13083-970, Campinas, SP, Brasil.

* A quem a correspondência deve ser enviada. 
was performed to assay bean characteristics after which they were broken into nibs $(3-6 \mathrm{~mm})$ prior to treatment.

Polyphenol oxidase (E.C. 1.14.18.1) from mushroom (Sigma, St Louis, MI, USA) with $5,350 U / \mathrm{mg}$ was used at a final concentration of $200 \mathrm{U} / \mathrm{mL}$. To $80 \mathrm{~g}$ of autoclaved cocoa nibs $\left(121^{\circ} \mathrm{C}\right.$ for $\left.15 \mathrm{~min}\right), 40 \mathrm{~mL}$ of enzyme solution was added. The sample was submitted to a vacuum of $200 \mathrm{mmHg}$ in a desiccator for $1 \mathrm{~min}$ to facilitate the penetration of the enzyme solution.

To evaluate the effect of air on enzyme action, the sample was placed in a glass column. The height of the packed sample was $10 \mathrm{~cm}$ and the internal diameter was $3 \mathrm{~cm}$. An air flow of $250 \mathrm{~L} / \mathrm{h}$ was passed through the column. To verify the effect of air alone an experiment was done with water instead of the enzyme solution. Controlled experiments were conducted without air by placing the samples with enzyme or water into beakers.

The experiments were conducted at ambient temperature and aliquots were taken at $0,0.5,1,2$ and 3 hours of treatment. The samples were dried at $65^{\circ} \mathrm{C}$, defatted with petroleum ether and stored at $-18^{\circ} \mathrm{C}$ until the analysis.

\section{2 - Total phenol analysis}

Total phenols were determined by the Prussian Blue assay as follows. Fifty $\mathrm{mg}$ of defatted sample were extracted twice with $5 \mathrm{~mL}$ of acetone:water $(7: 3, \mathrm{v} / \mathrm{v})$ at $4^{\circ} \mathrm{C}$, centrifuged for $10 \mathrm{~min}$ at $4100 \mathrm{xg}$ and the supernatants were combined. An aliquot of $0.1 \mathrm{~mL}$ was added to $50 \mathrm{~mL}$ of distilled water followed by the addition of $3.0 \mathrm{~mL}$ of $0.10 \mathrm{M} \mathrm{FeNH}_{4}\left(\mathrm{SO}_{4}\right)_{2}$ in $0.10 \mathrm{M} \mathrm{HCl}$. After exactly 20 min, $0.008 \mathrm{M} \mathrm{K}_{3} \mathrm{Fe}(\mathrm{CN})_{6}$ was added. The absorbancy was read after $20 \mathrm{~min}$ at $720 \mathrm{~nm}$ [11]. A standard curve was constructed using tannic acid and the results expressed as mg phenols/g sample.

\section{3 - Tannins analysis}

Fifty $\mathrm{mg}$ of defatted samples were extracted three times $(3,3$ and $4 \mathrm{~mL})$ with methanol:water $(1: 1, \mathrm{v} / \mathrm{v})$ and centrifuged for $5 \mathrm{~min}$ at $4100 \mathrm{~g}$ and the supernatants were combined. To an aliquot of $1 \mathrm{~mL}, 2 \mathrm{~mL}$ of BSA (bovine serum albumin, Type $5,1 \mathrm{mg} / \mathrm{mL}$ in $0.20 \mathrm{M} \mathrm{CH}_{3} \mathrm{COOH}$ : $0.17 \mathrm{M} \mathrm{NaCl}$ buffer, $\mathrm{pH} 4.9$ ) was added. The sample was immediately mixed and maintained at $4^{\circ} \mathrm{C}$ for 24 hours for tannin precipitation. After a centrifugation at $4100 \mathrm{~g}$ for $15 \mathrm{~min}$, the supernatant was discarded and the precipitate dissolved in $4 \mathrm{~mL}$ SDS:TEA $(10 \mathrm{~g} / \mathrm{L}$ SDS and $50 \mathrm{~mL} / \mathrm{L}$ triethanolamine). Then, $1 \mathrm{~mL}$ of $0.01 \mathrm{M}$ $\mathrm{FeCl}_{3}$ in $0.01 \mathrm{M} \mathrm{HCl}$ was added and mixed well. After 15 min the absorbancy was read at 510nm [5]. A standard curve was constructed with tannic acid and the results were expressed as mg tannic acid/g sample.

\section{4 - Statistics}

Each treatment was performed three times and each sample was analysed three times. The results were compared by analysis of variance using the software package Statistica version 5.0. Significant differences among means were confirmed using the Tukey test for multiple comparisons at $P<0.05$.

\section{3 - RESULTS AND DISCUSSION}

The cut test revealed a large proportion (25/100) of violet beans, which indicated under-fermentation. The total phenol content was $7.9 \mathrm{mg} / \mathrm{g}$ and the tannin content $2.6 \mathrm{mg} / \mathrm{g}$. The results for total phenols and tannin are shown in Tables 1 and 2, respectively. Total phenol content in the sample treated with water and air had no significant change during the process, but tannin content presented a significant decrease. In the sample treated with water, the total phenol content was reduced at $0.5 \mathrm{~h}$ and returned gradually to the initial value, but tannin content after an initial increase until 1 hour remained unchanged after that. For the sample treated with enzyme and air there was a large increase of total phenols at the beginning of the process until $0.5 \mathrm{~h}$ followed by a decrease to the initial value. The same could be observed for tannin content. On the other hand, the enzyme treated sample without air had little decrease in total phenol content at the beginning of the process and this value remained unchanged for 3 hours. The tannin content was the same as that of the sample treated with enzyme and air. Figure 1 shows the percentage contribution of tannin to total phenols. The samples treated with air had a lower tannin percentage, which indicated that air had a positive effect on tannin content reduction, especially in the sample treated with water and air.

TABLE 1. Total Phenol content (mg tannic acid/g sample) in cocoa nibs after treatment with PPO, air and water.

\begin{tabular}{ccccc}
\hline & \multicolumn{4}{c}{ Sample } \\
\cline { 2 - 5 } Time $(\mathrm{h})$ & $\mathrm{PPO}+\mathrm{Air}$ & $\mathrm{PPO}$ & $\mathrm{H}_{2} \mathrm{O}+$ Air & $\mathrm{H}_{2} \mathrm{O}$ \\
\hline 0 & $7.9 \pm 0.4 \mathrm{a}, \mathrm{A}$ & $7.9 \pm 0.4 \mathrm{a}, \mathrm{A}$ & $7.9 \pm 0.4 \mathrm{a}, \mathrm{A}$ & $7.9 \pm 0.4 \mathrm{a}, \mathrm{A}$ \\
0.5 & $10.4 \pm 0.7 \mathrm{~b}, \mathrm{~A}$ & $6.8 \pm 0.2 \mathrm{~b}, \mathrm{~B}$ & $8.4 \pm 0.6 \mathrm{a}, \mathrm{C}$ & $5.9 \pm 0.1 \mathrm{~b}, \mathrm{D}$ \\
1 & $8.6 \pm 0.4 \mathrm{a}, \mathrm{A}$ & $6.4 \pm 0.5 \mathrm{~b}, \mathrm{~B}$ & $8.5 \pm 0.9 \mathrm{a}, \mathrm{A}$ & $6.4 \pm 0.8 \mathrm{~b}, \mathrm{~B}$ \\
2 & $8.2 \pm 0.1 \mathrm{a}, \mathrm{A}$ & $6.3 \pm 0.5 \mathrm{~b}, \mathrm{~B}$ & $8.8 \pm 0.9 \mathrm{a}, \mathrm{A}$ & $6.4 \pm 0.1 \mathrm{~b}, \mathrm{~B}$ \\
3 & $7.9 \pm 0.2 \mathrm{a}, \mathrm{A}$ & $6.5 \pm 0.6 \mathrm{~b}, \mathrm{~B}$ & $7.9 \pm 0.6 \mathrm{a}, \mathrm{A}$ & $7.3 \pm 0.1 \mathrm{a}, \mathrm{A}$
\end{tabular}

Values are mean \pm S.D. Means within the same treatment followed by the same lower case letters are not significantly different at $p<0.05$. Means within the same time ollowed by the same upper case capital letters are not significantly different at $p<$

TABLE 2. Tannin content (mg tannic acid/g sample) in cocoa nibs after treatment with PPO, air and water.

\begin{tabular}{clllc}
\hline & \multicolumn{4}{c}{ Sample } \\
\cline { 2 - 5 } Time (h) & PPO + Air & \multicolumn{1}{c}{ PPO } & \multicolumn{1}{c}{$\mathrm{H}_{2} \mathrm{O}+$ Air } & $\mathrm{H}_{2} \mathrm{O}$ \\
\hline 0 & $2.6 \pm 0.6 \mathrm{a}, \mathrm{b}, \mathrm{A}$ & $2.6 \pm 0.6 \mathrm{a}, \mathrm{b}, \mathrm{A}$ & $2.6 \pm 0.6 \mathrm{a}, \mathrm{b}, \mathrm{A}$ & $2.6 \pm 0.6 \mathrm{a}, \mathrm{A}$ \\
0.5 & $3.5 \pm 0.6 \mathrm{a}, \mathrm{A}$ & $3.6 \pm 0.4 \mathrm{a}, \mathrm{A}$ & $2.9 \pm 0.6 \mathrm{a}, \mathrm{A}$ & $2.9 \pm 0.5 \mathrm{a}, \mathrm{A}$ \\
1 & $3.1 \pm 0.6 \mathrm{a}, \mathrm{A}$ & $3.1 \pm 0.2 \mathrm{a}, \mathrm{b}, \mathrm{A}$ & $3.1 \pm 0.2 \mathrm{a}, \mathrm{A}$ & $3.3 \pm 0.2 \mathrm{a}, \mathrm{A}$ \\
2 & $2.7 \pm 0.1 \mathrm{a}, \mathrm{A}$ & $2.7 \pm 0.1 \mathrm{~b}, \mathrm{~A}$ & $2.1 \pm 0.1 \mathrm{~b}, \mathrm{~B}$ & $3.3 \pm 0.2 \mathrm{a}, \mathrm{C}$ \\
3 & $2.2 \pm 0.3 \mathrm{~b}, \mathrm{~A}$ & $2.5 \pm 0.3 \mathrm{~b}, \mathrm{~A}$ & $1.7 \pm 0.1 \mathrm{c}, \mathrm{B}$ & $3.3 \pm 0.1 \mathrm{a}, \mathrm{C}$ \\
\hline
\end{tabular}

Values are mean \pm S.D. Means within the same treatment followed by the same lower case letters are not significantly different at $p<0.05$. Means within the same time followed by the same upper case capital letters are not significantly different at $p<$ 0.05 .

A simple explanation of these transformations is very difficult since PPO promotes o-hydroxylation of monophenols and the oxidation of $o$-diphenols to $o$-quinones. 
The o-quinones also take part in secondary reactions with compounds like anthocyanins and many other phenolic compounds, which reduce o-quinones to diphenols, or can condense with phenolic compounds [18]. A study of astringency and bitterness of flavan-3ol monomers, dimers and trimers revealed that molecular size was the major factor influencing the sensory properties of these attributes. As molecular size increased, bitterness decreased and astringency increased [9]. The use of PPO without air also contributed to reduction of astringency and bitterness in cocoa nibs, and improved the acceptance of a chocolate formulated with treated cocoa [3]. Despite the changes observed in PPO treated samples we achieved a greater tannin reduction in the treatment with water and air.

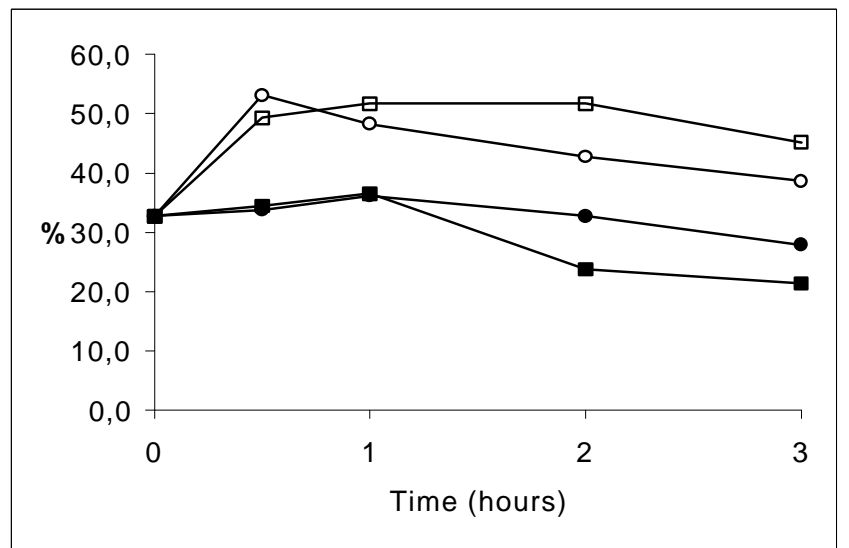

FIGURE 1. Tannin percentage in relation to total phenol in cocoa nibs treated with PPO + air $(\bullet)$, PPO (O), $\mathrm{H}_{2} \mathrm{O}+\operatorname{air}(\boldsymbol{\square})$ and $\mathrm{H}_{2} \mathrm{O}(\square)$.

The polyphenol oxidase from mushrooms reduced the total phenol content in cocoa nibs by $20 \%$, which was lower than that obtained by PPO of Coriolus versicolor for the same time of treatment [19] and of Anona squamosa after 6 hours of treatment [3], both presented a $25 \%$ reduction. Tannin content was not reduced by mushroom PPO, whereas it was reduced by PPO from other sources $[3,19]$. This could be explained by different experimental conditions and/or different specificity of the enzyme studied. Cocoa beans are known to have different $\mathrm{pH}$ and polyphenol content, depending on their origin and fermenting practices.

\section{4 - CONCLUSION}

Despite the use of PPO, tannin content was significantly reduced by air application. These findings indicated that air processing of cocoa nibs could help in cocoa flavour improvement by changing the ratio between tannin and total phenol content and, consequently, the astringency and bitterness of insufficiently fermented beans. Further studies are needed to understand the specific transformations of phenolic compounds during air processing of cocoa.

\section{5 - REFERENCES}

[1] BARTOLOMÉ, B.; JIMÉNEZ-RAMSEY, L.M.; BUTLER, L.G. Nature of the condensed tannins present in the dietary fibre fractions in foods. Food Chemistry, v. 53, n.4, p. 357-362, 1995.

[2] CROS, E.; VILLENEUVE, F.; VINCENT, J.-C. Recherche d'un indice de fermentation du cacao I: Evolution des tanins et des phénols totaux de la fève. Café, Cacao, Thé, v. 26, n. 2, p. 109-114, 1982.

[3] FERNÁNDEZ BARBERY, S.D. Estudo do melhoramento do sabor de cacau (Theobroma cacao L.) utilizando polifenoloxidase extraida da pinha (Annona squamosa L.) e tratamento térmico não convencional. Campinas, 1999, 76p. Dissertação Mestrado. UNICAMP.

[4] FORSYTH, W.G.C.; QUESNEL, V.C. Advances Enzymology, v. 25, p. 457, 1963. Apud BIEHL, B.; PASSERN, U.; PASSERN, D. Subcellular structures in fermenting cocoa beans. Effect of aeration and temperature during seed and fragment incubation. Journal Science Food Agriculture, v.28, p. 41-52, 1977.

[5] HAGERMAN, A.E.; BUTLER, L.G. Protein Precipitation method for the quantitative determination of tannins. Journal Agriculture Food Chemistry. v. 26, n.4, p. 809-812, 1978.

[6] HANSEN, C. E.; OLMO, M.; BURRI, C. Enzyme activities in cocoa beans during fermentation. Journal Science Food Agriculture, v. 77, p. 273-281, 1998.

[7] KNAPP, A.W. The fermentation of cacao. Journal Society Chemical Industry. v. 43, p. 402, 1924. Apud ROELOFSEN, P.A. Fermentation, drying, and storage of cacao beans. Advances Food Research, v.8, p. 225-296, 1958.

[8] MOTODA, S. Formation of Aldehydes from amino acids by polyphenol oxidase. Journal Fermentation Technology, v. 57, n. 5, p. 395-399, 1979.

[9] PELEG, H., GACON, K. SCHLICH, P., NOBLE, A.C. Bitterness and astringency of flavan-3-ol monomers, dimers and trimers. Journal Science Food Agriculture. v.79, p. 1123-1128,1999.

[10] PORTER, L.J.; MA, Z.; CHAN, B.G. Caco procyanidins: Major flavanoids and identification of some minor metabolites. Phytochemistry, v. 30, n. 5, p. 1657-1663, 1991.

[11] PRICE, M.L.; Butler, L.G. Rapid visual estimation and spectrophotometric determination of tannin content of sorghum grain. Journal Agriculture Food Chemistry, v. 25, n. 6, p. 1268-1273, 1977.

[12] REEVES, S.G.; McDOWELL, I.; BEHN, K.; DENCH, J. Biochemical studies of cocoa bean o-diphenol $\mathrm{O}_{2}$ oxidoredutase (catechol oxidase). Food Chemistry, v. 29, n. 3, p. 209-219, 1988.

[13] RIGAUD, J.; ESCRIBANO-BAILON, M.T.; PRIEUR, C.; SOUQUET, J.M.; CHAYNIER, V. Normal-phase high-performance liquid chromatographic separation of procyanidins from cacao beans and grape seeds. Journal Chromatography A, v. 654, n. 2, p. 255-260, 1993.

[14] VILLENEUVE, F.; CROS, E.; MACHEIX, J.J. Effet de la fermentation sur les activités peroxidasiques et polyphénoloxydasiques de la fève de cacao. Café, Cacao, Thé, v. 29, n. 2, p. 113-120, 1985.

[15] VILLENEUVE, F.; CROS, E.; VINCENT, J.C.; MACHEIX, J.J. Recherche d'un indice de fermentation du cacao. III Evolution des flavan-3-ols de la fève. Café, Cacao, Thé, v. 33, n. 3, p. 165-170, 1989. 
[16] WOLLGAST, J.; ANKLAM, E. Review on polyphenols in Theobroma cacao: changes in composition during manufacture of chocolate and methodology for identification and quantification. Food Research International. v.33, p. 423-447, 2000.

[17] WOLLGAST, J., ANKLAM, E. Polyphenols in chocolate: is there a contribution to human health? Food Research International. v.33, p. 449-459, 2000.
[18] WONG, D.W.S. 1989. Mechanism and Theory in Food Chemistry. AVI, New York.

[19] YOSHIYAMA, M.; ITO, Y. Decrease of astringency of cacao beans by an enzymatic treatment. Nippon Shokuhin Kagaku Kaishi, v.43, n.2, p. 124-129, 1996. 